\title{
Role of photorefractoriness in onset of anoestrus in Rambouillet $\times$ Dorset ewes
}

\author{
J. E. Minton \\ Department of Animal Sciences and Industry, Kansas State University, Manhattan, Kansas 66506, \\ $U S A$
}

\begin{abstract}
Summary. An experiment was conducted to determine the extent to which refractoriness to short daylength is involved in the onset of anoestrus in Rambouillet $\times$ Dorset ewes. Ovary-intact ewes $(\mathrm{N}=36)$ were exposed to ambient photoperiod $(\mathrm{C})$ or to a photoperiod equal to the winter solstice (S) beginning on 21 December 1986 and continuing until 21 April 1987. Samples of serum were obtained at weekly intervals and assayed for progesterone to assess ovarian activity, and for prolactin to assess response to photoperiod treatment. In addition, ovariectomized (ovx) ewes with implants containing oestradiol were housed with $\mathrm{C}\left(\mathrm{C}_{\mathrm{ovx}}\right)$ and $\mathrm{S}\left(\mathrm{S}_{\text {ovx }}\right)$ ewes $(\mathrm{N}=4$ per treatment $)$. The concentration of $\mathrm{LH}$ was determined in serum collected biweekly from all ovariectomized ewes throughout the treatment period as an index of reproductive status. Time-trends for concentrations of LH differed $(P<0.005)$ for ewes in Groups $\mathrm{C}_{\mathrm{ovx}}$ and $\mathrm{S}_{\mathrm{ovx}}$ with LH decreasing on the order of about 8-fold in Group $\mathrm{C}_{\mathrm{ovx}}$ through the treatment period, while not changing appreciably in Group $\mathrm{S}_{\mathrm{ovx}}$. Intact ewes in both treatments began to become anoestrous by the 9th week of treatment (about the last week in February). However, fewer Group $S$ than Group $C$ ewes were anoestrous at 13 and 14 weeks of treatment $(P=0.09)$. Time-trends for concentrations of prolactin also differed for the Group $\mathrm{C}$ and $\mathrm{S}$ ewes $(P<0.005)$, probably reflecting the divergence in duration of photoperiod between the two treatments by the end of the study. The results suggest that reproductive and endocrine functions of Rambouillet $\times$ Dorset ewes can be supported by continued exposure to short days, even while a percentage of ewes housed in natural photic conditions experience anoestrus.
\end{abstract}

Keywords: photoperiod; refractoriness; ewes

\section{Introduction}

In general, ewes of most breeds that inhabit the temperate zones have periods of reproductive quiescence, but there is considerable variation among breeds in the degree of seasonality (reviewed by Ortavant $e t$ al., 1988). For example, whereas essentially all Suffolk ewes did not cycle between about March and August (Robinson \& Karsch, 1984), it was not unusual for Dorset (Hall et al., 1986) and Rambouillet (Wiggins et al., 1970) ewes to have regular oestrous cycles during that same period of time. Similarly, whereas no Welsh Mountain ewes cycled between May and October, about $15 \%$ of Dorset Horn ewes cycled throughout the year (Webster \& Haresign, 1983). Part of the difference among breeds (genotypes) of ewes for their degree of seasonality may reside in greater sensitivity to the negative feedback action of oestradiol on the secretion of LH (Thomas et al., 1988), a characteristic of oestradiol known to intensify greatly during the transition into anoestrus (reviewed by Karsch, 1980; Karsch et al., 1984).

An additional emerging concept of photoperiodism and seasonality of reproduction in sheep is that of photorefractoriness. There is compelling evidence that the onset of anoestrus in the late 
winter/early spring is not brought on by the arrival of long days; rather, the ewe ceases to continue regular oestrous cycles because she has become insensitive to stimulatory short days (Worthy \& Haresign, 1983; Robinson \& Karsch, 1984; Malpaux et al., 1987). Similarly, ewes begin to have oestrous cycles in the late summer/early fall, not because they are actively driven by the arrival of short days, but because they are no longer inhibited by relatively long days (Robinson et al., 1985b; Worthy et al., 1985). In addition, rams that are kept in constant short or long photoperiods also become refractory and eventually lose the ability to couple secretion of prolactin with the prevailing photoperiod (Almeida \& Lincoln, 1984).

It is not unusual for greater than $50 \%$ of Dorset (Nugent et al., 1988), Rambouillet (Wiggins et al., 1970), and crossbred ewes containing Rambouillet and Dorset breeding (J. E. Minton, unpublished) to have oestrous cycles during the months of April through June. At this time, Suffolk ewes are expected to be anoestrous (Robinson \& Karsch, 1984), because they have become refractory to the stimulatory action of short days (Robinson \& Karsch, 1984; Malpaux et al., 1987). Part of the variation in seasonality of reproduction among these breeds of sheep may reside in the degree to which photorefractoriness is involved in the termination of the breeding season. Therefore, an experiment was designed to evaluate the development of refractoriness to short days in Rambouillet $\times$ Dorset ewes.

\section{Materials and Methods}

Animals. Fall-lambing Rambouillet $\times$ Dorset ewes were utilized in the experiment. While they were still nursing lambs and before the onset of the experiment, the flock was exposed to a vasectomized ram whose brisket was smeared with coloured grease. Only ewes with evidence of initiation of cyclicity, based upon the presence of grease marks on their rumps, were used in the experiment. The occurrence of oestrous cycles in these ewes was confirmed later after evaluation of concentrations of progesterone in serum (detailed below). The vasectomized ram was removed before the assignment of ewes to treatments.

Ten ewes from the flock described above were ovariectomized 2 weeks before the onset of the experiment. At the time of ovariectomy, each ewe received a Silastic implant ( $3.175 \mathrm{~mm}$ i.d., $4.765 \mathrm{~mm}$ o.d.) containing a 30 -mm column of packed, crystalline oestradiol- $17 \beta$ in the axillary region. The construction of these implants was patterned after that reported by Goodman et al. (1982).

Treatments. Ovary-intact, cycling ewes $(\mathrm{N}=36$ ) were assigned randomly to receive ambient photoperiod (and temperature) from 21 December 1986 to 21 April 1987 (C ewes, $N=18$ ) or a photoperiod $(9 \cdot 5 \mathrm{~h}$ ) that approximately equalled the winter solstice at Manhattan, KS, USA $\left(39^{\circ} 12^{\prime} \mathrm{N}\right)(\mathrm{S}$ ewes, $\mathrm{N}=18)$. To accomplish the solstice photoperiod, lights in two environmentally controlled rooms were set to come on at 07:30 h and go off at 17:00 h. Animals in Group $S$ were moved into these rooms in the afternoon, just before $17: 00 \mathrm{~h}$, and turned back outdoors after $07: 30 \mathrm{~h}$ the following morning. Thus, Group S ewes only spent nights in the rooms and were otherwise mingled with Group C ewes during the day. Ewes in Group $\mathrm{C}$ also were confined outdoors during the time that the Group S ewes were housed indoors. In addition to the ovary-intact ewes in each treatment group, ovariectomized ewes implanted with capsules containing oestradiol were maintained with ewes in Groups $\mathrm{C}$ and $\mathrm{S}$ and were designated Group $\mathrm{C}_{\text {ovx }}(\mathrm{N}=5)$ and Group $\mathrm{S}_{\mathrm{ovx}}(\mathrm{N}=5)$, respectively. Since the nightly fall in ambient temperature to which ewes in Groups $\mathrm{C}$ and $\mathrm{C}_{\mathrm{ovx}}$ were exposed could not be duplicated precisely for $\mathrm{S}$ and $\mathrm{S}_{\mathrm{ovx}}$ ewes, the temperature in the environmental rooms was held at $5^{\circ} \mathrm{C}$ from $17: 00$ to $07: 30 \mathrm{~h}$ throughout the study.

Reproductive and endocrine endpoints. The occurrence of regular oestrous cycles in ewes in Groups $\mathrm{C}$ and $\mathrm{S}$ was tracked by evaluating the concentration of progesterone in serum collected at weekly intervals throughout the study. Because the ewes were known to be reproductively active at the onset of the study (by design), a ewe was considered to have become anoestrous when she failed to have progesterone in serum that exceeded $1 \mathrm{ng} / \mathrm{ml}$ for more than two consecutive samples. Examples of profiles of progesterone that were considered to indicate ewes that were cycling throughout the entire study; cycling at the onset of treatment, but becoming anoestrous; and cycling at the onset of treatment, having a period of time without luteal function, then reinitiating oestrous cycles are illustrated in Fig. 1. The occurrence of the last type of profile was surprising, although it was evident in only 3 Group C ewes and 1 Group $S$ ewe. This type of profile is similar to the 'intermittent' cyclicity described by Nugent $e t$ al. (1988) for Dorset ewes in spring. Prolactin was also quantified in serum collected weekly from these ewes to assess treatment-induced changes in perception of duration of photoperiod.

The concentration of $\mathrm{LH}$ in serum collected twice weekly from ewes in Groups $\mathrm{C}_{\mathrm{ovx}}$ and $\mathrm{S}_{\mathrm{ovx}}$ was determined, and then the average concentration for the week was calculated from the concentration in these two samples. During the course of the experiment, oestradiol implants were lost from 1 Group $C_{o v x}$ ewe and 1 Group $S_{o v x}$ and so the data from these ewes were not included in the analysis. The concentration of $\mathbf{L H}$ in ovariectomized ewes given implants of oestradiol has been utilized repeatedly as an indicator of reproductive status in Suffolk ewes (Legan et al., 1977; Legan 


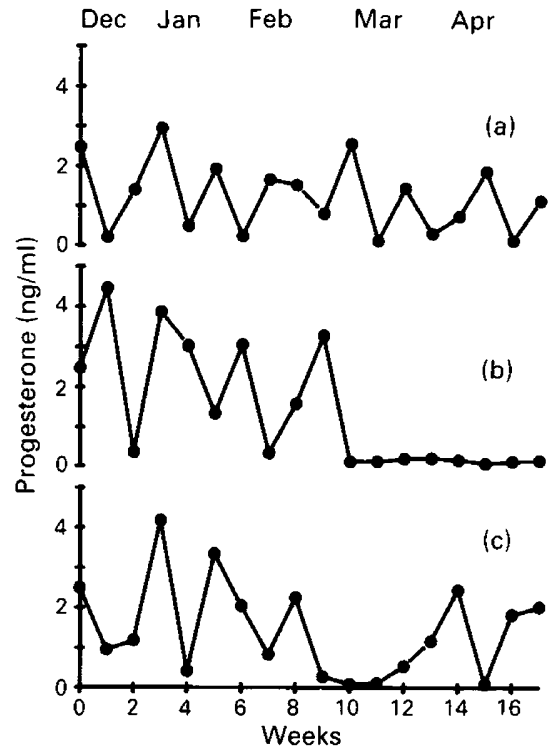

Fig. 1. Examples of profiles of progesterone in serum of ewes interpreted to be cycling continuously (a); cycling, then becoming anoestrous (b); and cycling, becoming anoestrous, then reinitiating oestrous cycles (c).

\& Karsch, 1980; Goodman \& Karsch, 1981; Bittman et al., 1983a, b; Robinson \& Karsch, 1984, 1987; Robinson et al. 1985a, b; Karsch et al., 1986; Malpaux et al., 1987; Thomas et al., 1988), Dorset Horn ewes (Worthy \& Haresign, 1983; Worthy et al., 1985) and Dorset ewes (Thomas et al., 1988).

Assays for progesterone, $\mathbf{L H}$ and prolactin. Progesterone was quantified in serum by radioimmunoassay similar to that described for bovine serum (Skaggs et al., 1986). When 50, 100, 250 and 500 pg progesterone were added to ovine serum and assayed, $47 \cdot 2,103 \cdot 1,268 \cdot 1$ and $543 \cdot 3 \mathrm{pg}$ were recovered, respectively (average recovery $=103 \cdot 3 \%$ ). Extraction of $50,100,150,200$ and $250 \mu$ lof ewe serum yielded concentrations of $0.32,0.23,0.27,0.28$ and $0.24 \mathrm{ng}$ progesterone $/ \mathrm{ml}$, respectively. The assay was sensitive (mean binding of $B_{o}$ tubes minus two s.d.) to $6.74 \mathrm{pg} /$ assay tube, and the intra- and interassay coefficients of variation averaged $6 \cdot 2 \%$ and $10 \cdot 8 \%$, respectively, for 5 assays.

The assays for $\mathrm{LH}$ and prolactin in sheep serum were similar to those described for $\mathrm{LH}$ in pig serum (Newton et al., 1987). For the LH assay, ovine LH, LER-1056-C2, was used as standard and iodinated for tracer. The antibody was DJB-3-1211, raised in rabbits against ovine LH. Cross-reactivities of the antibody with NIADDK-oGH-I-1, NIADDK-oFSH-I-1 and LER-860-2 (prolactin) were $0.2 \%, 8 \cdot 7 \%$ and $<0.1 \%$, respectively. Serial dilutions of ewe serum displaced ${ }^{125}$ I-labelled ovine LH from the antibody in a manner similar to unlabelled LER-1056-C2. When $4,8,16,32$ and $64 \mathrm{ng}$ ovine $\mathrm{LH}$ were added to ovine serum, 2.6, 7.1, 13.6, 32.8 and 54.6 ng, respectively, were recovered (average of $85.4 \%$ ). The sensitivity of the assay was $0.03 \mathrm{ng} /$ assay tube $(0.1 \mathrm{ng} / \mathrm{ml} \mathrm{serum}$ ), and the intra- and interassay coefficients of variation averaged $18.9 \%$ and $2 \cdot 1 \%$, respectively, for 3 assays.

Ovine prolactin, LER-860-2, was used as assay standard and iodinated tracer for the prolactin assay. The antibody, NIADDK-Anti-oPRL-1, did not cross-react significantly with other pituitary hormones $(<0 \cdot 1 \%$ for LER1056-C2, NIADDK-oGH-I-1 and NIADDK-oFSH-I-1). When 10, 20, 40, 80, 160 and 320 ng prolactin were added to ovine serum, $11 \cdot 0,15 \cdot 5,29 \cdot 5,85 \cdot 5,187 \cdot 5$ and $283.5 \mathrm{ng}$, respectively, were recovered $(95.6 \%$ recovery). Serial dilutions of ovine serum displaced ${ }^{125} \mathrm{I}$-labelled prolactin from the antibody to produce a binding curve that paralleled the standard curve. The assay sensitivity was $0.05 \mathrm{ng} /$ assay tube $(0.17 \mathrm{ng} / \mathrm{ml}$ serum), and the intra- and interassay coefficients of variation averaged $4.0 \%$ and $5.9 \%$, respectively, for 3 assays.

Analysis. The proportion of ewes having reguiar oestrous cycles during the course of the experiment was analysed by $\chi^{2}$ tests. To analyse the $\mathrm{LH}$ and prolactin data, time was treated as a continuous, independent variable. The concentrations of hormones across weeks of the study were fitted to polynomial equations, and the resultant time-trends were tested for heterogeneity of regression, as described by Guilbault et al. (1985).

\section{Results}

The fitted profiles for $\mathrm{LH}$ in ewes in Groups $\mathrm{C}_{\mathrm{ovx}}$ and $\mathrm{S}_{\mathrm{ovx}}$ are illustrated in Fig. 2. Fourth-order polynomial equations were used to describe the time-trends for $\mathrm{LH}_{\text {across the treatment period }}$ 
$\left(\mathrm{R}^{2}=0.48\right)$, and these profiles differed for the two groups $(P<0.005)$. As expected, concentrations of $\mathrm{LH}$ were similar between the two treatments initially, but began to diverge as the experiment progressed. Concentrations of $\mathrm{LH}$ in serum fell generally below about $1 \mathrm{ng} / \mathrm{ml}$ for Group $\mathrm{C}_{\mathrm{ovx}}$ ewes, whereas LH was about 8-fold greater in Group $\mathrm{S}_{\mathrm{ovx}}$ ewes during the last 8 weeks of the experiment.

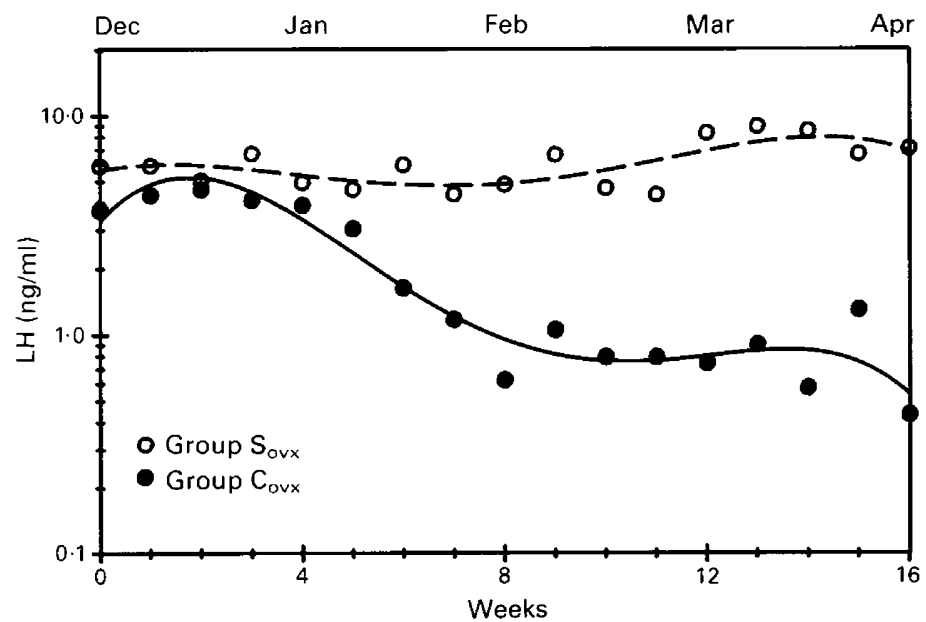

Fig. 2. Serum LH in ovariectomized ewes implanted with oestradiol and exposed to natural photoperiod (Group $\mathrm{C}_{\mathrm{ovx}}$ ) or a photoperiod equalling the winter solstice (Group $\mathrm{S}_{\mathrm{ovx}}$ ). Each point represents the mean concentration of $\mathrm{LH}$ in samples collected twice weekly from 4 ewes. The fitted time-trends in the figure differ $(P<0.005)$ for the two groups. The pooled standard error is $1.32 \mathrm{ng} / \mathrm{ml}$.

At the onset of the experiment, all of the intact Group $\mathrm{C}$ and $\mathrm{S}$ ewes were having regular oestrous cycles (Fig. 3). Beginning about the last week in February ( 9 weeks of treatment), ewes in both treatments began to become anoestrous. By 13 and 14 weeks of treatment, $55 \cdot 6 \%(10 / 18)$ of Group $\mathrm{C}$ ewes were anoestrous, but only $27.8 \%(5 / 18)$ of Group $\mathrm{S}$ ewes had ceased cycling $(P=$ $0 \cdot 09$ ). Thereafter, 3 Group $C$ ewes reinitiated ovarian cycles, and, although a greater proportion of Group S ewes (14/18) than Group C ewes (11/18) were cycling at the conclusion of the experiment, the difference was not statistically significant.

Concentrations of prolactin in serum of ewes in Groups $\mathrm{C}$ and $\mathrm{S}$ were fitted to seventh-order polynomial equations $\left(\mathrm{R}^{2}=0 \cdot 39\right)$, and the fitted time-trends differed between the two treatments $(P<0.005)$. Generally, prolactin varied between about 10 and $50 \mathrm{ng} / \mathrm{ml}$ for ewes in both groups through about the first 12 weeks of treatment. After this time, the profiles of concentrations of prolactin diverged, with concentrations in Group C ewes increasing dramatically (Fig. 4).

\section{Discussion}

In the present experiment, LH was used as an index of changes in sensitivity to oestradiol negative feedback potency in response to treatment. Clearly, Rambouillet $\times$ Dorset ewes exposed to ambient photoperiod underwent changes in oestradiol feedback potency, as described for other breeds of ewes. The magnitude of the change in LH during the onset of reproductive inhibition in these ewes is similar to that reported previously for ovariectomized, oestradiol-treated, Suffolk ewes (Bittman et al., 1983a). Of interest, however, is the observation in this experiment that continued exposure to a daylength equalling the shortest day of the year prevented this decline ing $_{9} \mathrm{LH}_{1} \mathrm{H}_{16 \mathrm{AM}}$ 


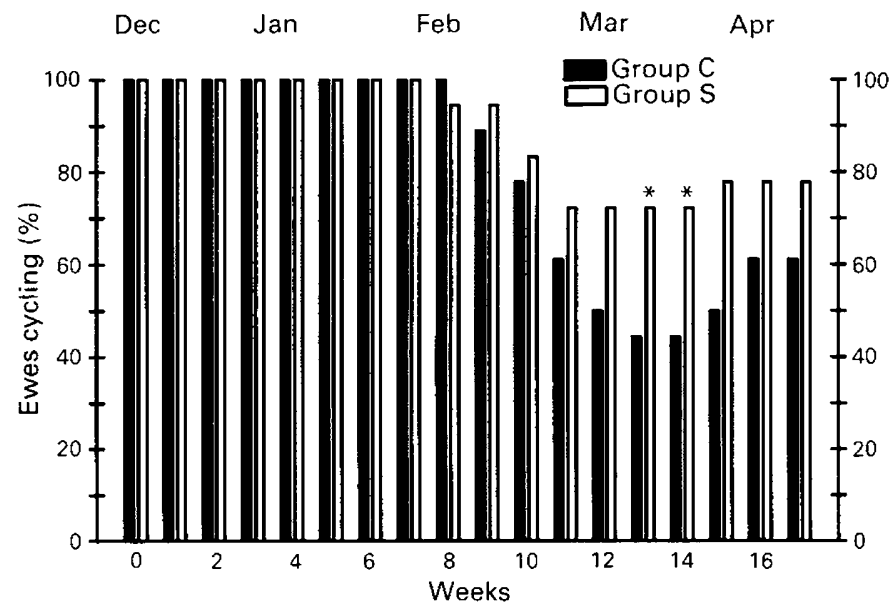

Fig. 3. Percentage of intact ewes ( $N=18$ per treatment) with oestrous cycles throughout the experiment. Ewes were exposed to natural photoperiod (Group C) or to a photoperiod equalling the winter solstice (Group S). Asterisks denote weeks of treatment when a greater proportion of Group $\mathrm{S}$ ewes than Group $\mathrm{C}$ ewes were cycling $(P=0 \cdot 09)$.

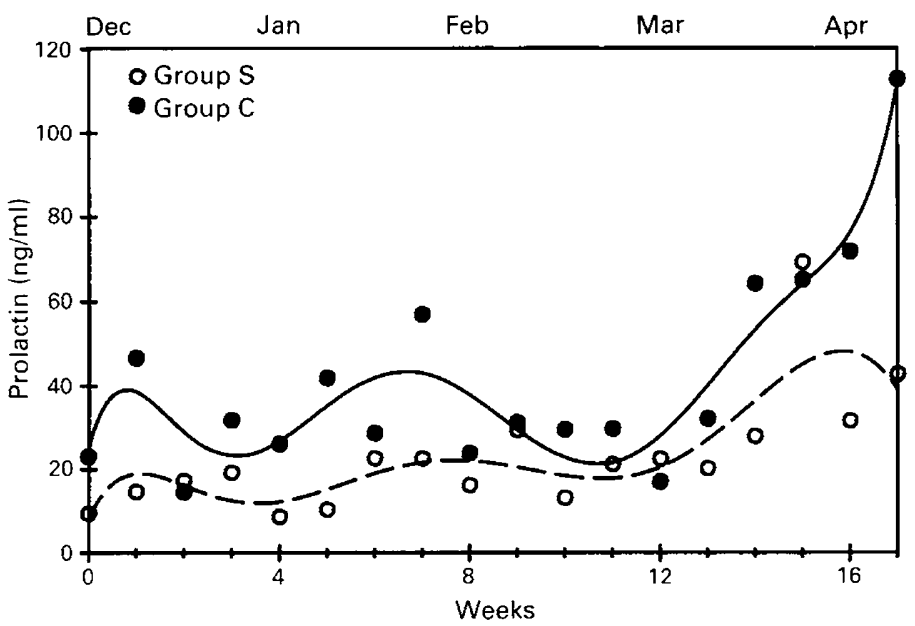

Fig. 4. Serum prolactin in intact ewes ( $N=18$ per treatment) exposed to natural photoperiod (Group C) or to a photoperiod equalling the winter solstice (Group S). Each point represents the mean concentration of prolactin from all ewes in each treatment. The fitted time-trends in the figure differ $(P<0.005)$ for the two groups. The pooled standard error is $6.76 \mathrm{ng} / \mathrm{ml}$.

In contrast, ovariectomized, oestradiol-implanted, Suffolk ewes kept in a solstice photoperiod became reproductively inhibited (as judged by the decline in serum LH) within about 60 days of the onset of the treatment (Robinson \& Karsch, 1984). Similarly, concentrations of LH in ovariectomized, oestradiol-treated, Dorset Horn ewes decreased within about 90 days of exposure to a short photoperiod similar in duration to the winter solstice (Worthy \& Haresign, 1983). Under ambient photoperiod, 'less seasonal' breeds of ewes experience a much less robust shift in oestradiol feedback potency during the transition into anoestrus than do 'more seasonal' breeds (Thomas et al., 1988). Perhaps this is the reason that LH remained elevated in ewes in Group $S_{\text {ovx }}$. The short photoperiod treatment used in the current study would be expected to result in $a_{a}$ stimulatory $_{09: 01: 16 \mathrm{AM}}$ 
melatonin signal (Malpaux et al., 1987), which could have continued to be stimulatory in the face of a relatively meagre increment in oestradiol feedback potency.

In the current experiment, intact Group $\mathrm{C}$ ewes began to cease cyclic ovarian activity during the middle to last part of February, which lagged behind the decrease in $\mathrm{LH}$ in serum of Group $\mathrm{C}_{\mathrm{ovx}}$ ewes by about 1 month. Ewes in Group $\mathrm{S}$ also began to become anoestrous over about the same time-course, but, through the months of March and April, the $S$ treatment supported oestrous activity of ewes to a greater extent than did the $\mathrm{C}$ treatment. Despite the occurrence of anoestrus in some ewes from both treatments, at no time were all of the ewes anoestrous during the course of the experiment. In fact, the percentage of ewes cycling never decreased below $40 \%$, even in Group C. This observation undoubtedly reflects the breed makeup of this cross and its tendency to have oestrous cycles throughout the year (Wiggins et al., 1970; Hall et al., 1986). On the other hand, virtually all Suffolk ewes are expected to be anoestrous at this time of year (Robinson \& Karsch, 1984), although the Suffolk ewe represents a breed known to be more highly seasonal, at least in comparison to the Merino ewe (Thomas et al., 1988).

The reproductive responses observed in this study provide additional information that may be helpful in understanding the endocrine responses to photoperiod underlying differences in seasonality of ewes attributable to genotype (breed). Some important differences among breeds of ewes are already clear. First, ewes from more highly seasonal breeds experience a greater change in sensitivity to oestradiol feedback potency on LH than do those from less seasonal breeds (Thomas et al., 1988), and, clearly, seasonal changes in feedback potency are critical in defining breeding seasons in ewes (Karsch et al., 1984). In addition, anoestrous Dorset ewes are stimulated to ovulate to a greater extent in response to ram exposure than are anoestrous Hampshire ewes in April and May (Nugent et al., 1988). The present study demonstrates that differences in seasonality among breeds of sheep may be related, in part, to the degree to which photorefractoriness governs the transition into anoestrus. Although refractoriness to the prevailing photoperiod clearly is involved in the transition into anoestrus in Suffolk sheep (Robinson \& Karsch, 1984; Malpaux et al., 1987) and is suggested even for Dorset Horn sheep (Worthy \& Haresign, 1983), data from the current study suggest that some breeds or breed crosses continue to be reproductively responsive to prolonged, unchanging, short photoperiods. The possibility cannot be ruled out that Group $\mathrm{S}$ ewes also would have become refractory given additional exposure to the treatment. In fact, it would be argued that some Group S ewes were already refractory since the short photoperiod could not prevent all of these ewes from becoming anoestrous. Alternatively, differences in the proportion of Group $\mathrm{S}$ and $\mathrm{C}$ ewes cycling may have become even greater upon additional exposure to the treatments had greater numbers of Group $C$ ewes become anoestrous, while the proportion of Group $S$ ewes cycling remained stable. In any event, the results bring into question the importance of photorefractoriness in underlying seasonal changes in cyclicity in Rambouillet $\times$ Dorset ewes under natural environmental conditions.

Finally, prolactin was evaluated in the current experiment, because prolactin secretion in sheep changes in response to photoperiod (Ravault, 1976; Ravault \& Ortavant, 1977; Lincoln, 1979; Webster \& Haresign, 1983; Worthy \& Haresign, 1983; Worthy et al., 1985). The rationale was that if Group $\mathrm{S}$ ewes became refractory to their photic environment, prolactin would become uncoupled to the prevailing photic conditions. Such an uncoupling of prolactin and photoperiod occurs in Soay rams kept in short days (Almeida \& Lincoln, 1984). However, prolactin tended to remain lower in Group $\mathrm{S}$ than in Group $\mathrm{C}$ ewes, especially by the conclusion of the study, probably reflecting the gradual widening of the daylength between these two treatments. In agreement with this observation are the data of Worthy \& Haresign (1983), in which prolactin continued to be secreted in accord with the photoperiod in ewes kept in short days. Again, the possibility that secretion of prolactin might have eventually become inappropriate to the photoperiod in Group S ewes, had they been kept in that treatment for a greater period of time, cannot be discounted.

In conclusion, the present results suggest that prolonged exposure to an unchanging, short photoperiod can continue to support reproductive and endocrine functions in Rambouillet $\times$ $\times$ a 
Dorset ewes. Further, refractoriness to short days may not be a physiologically significant event in determining reproductive status in ewes representing breeds that are not highly seasonal.

This manuscript is contribution number 90-92-J of the Kansas Agricultural Experiment Station. I thank Dr D. J. Bolt, U.S.D.A. Animal Hormone Program, Dr Leo Reichert, Albany Medical College and the National Hormone and Pituitary Program for assay reagents; Dr Guy Kiracofe for technical assistance; K. Parsons and A. Gulbransen for assistance with data collection; and G. Weir for final preparation of the manuscript.

\section{References}

Almeida, O.F.X. \& Lincoln, G.A. (1984) Reproductive photorefractoriness in rams and accompanying changes in the patterns of melatonin and prolactin secretion. Biol. Reprod. 30, 143-158.

Bittman, E.L., Dempsey, R.J. \& Karsch, F.J. (1983a) Pineal melatonin secretion drives the reproductive response to daylength in the ewe. Endocrinology 113 , 2276-2283.

Bittman, E.L., Karsch, F.J. \& Hopkins, J.W. (1983b) Role of the pineal gland in ovine photoperiodism: Regulation of seasonal breeding and negative feedback effects of estradiol upon luteinizing hormone secretion. Endocrinology 113, 329-336.

Goodman, R.L. \& Karsch, F.J. (1981) A critique of the evidence on the importance of steroid feedback to seasonal changes in gonadotrophin secretion. $J$. Reprod. Fert., Suppl. 30, 1-13.

Goodman, R.L., Bittman, E.L., Foster, D.L. \& Karsch, F.J. (1982) Alterations in the control of luteinizing hormone pulse frequency underlie the seasonal variation in estradiol negative feedback in the ewe. Biol. Reprod. 27, 580-589.

Guilbault, L.A., Thatcher, W.W., Collier, R.J. \& Wilcox, C.J. (1985) Periparturient endocrine changes of conceptus and maternal units in Holstein heifers bearing genetically different conceptuses. J. Anim. Sci. 61, $1505-1515$.

Hall, D.G., Fogarty, N.M. \& Gilmour, A.R. (1986) Seasonality of ovulation and estrus, and the ram effect in Poll Dorset ewes. Theriogenology 25, 455-461.

Karsch, F.J. (1980) Seasonal reproduction: A saga of reversible fertility. The Physiologist 23, 29-38.

Karsch, F.J., Bittman, E.L., Foster, D.L., Goodman, R.L., Legan, S.J. \& Robinson, J.E. (1984) Neuroendocrine basis of seasonal reproduction. Recent Prog. Horm. Res. 40, 185-232.

Karsch, F.J., Bittman, E.L., Robinson, J.E., Yellon, S.M., Wayne, N.L., Olster D.H. \& Kaynard, A.H. (1986) Melatonin and photorefractoriness: loss of response to the melatonin signal leads to seasonal reproductive transitions in the ewe. Biol. Reprod. 34, 265-274.

Legan, S.J. \& Karsch, F.J. (1980) Photoperiodic control of seasonal breeding in ewes: modulation of the negative feedback action of estradiol. Biol. Reprod. 23, 1061-1068.

Legan, S.J., Karsch, F.J. \& Foster, D.L. (1977) The endocrine control of seasonal reproductive function in the ewe: A marked change in response to the negative feedback action of estradiol on luteinizing hormone secretion. Endocrinology 101, 818-824.
Lincoln, G.A. (1979) Light-induced rhythms of prolactin in the ram and the effect of cranial sympathectomy. Acta endocr., Copenh. 91, 421-427.

Malpaux, B., Robinson, J.E., Brown, M.B. \& Karsch, F.J. (1987) Reproductive refractoriness of the ewe to inductive photoperiod is not caused by inappropriate secretion of melatonin. Biol. Reprod. 36, 1333-1341.

Newton, E.A., Stevenson, J.S., Minton, J.E. \& Davis, D.L. (1987) Endocrine changes before and after weaning in response to boar exposure and altered suckling in sows. J. Reprod. Fert. 81, 599-609.

Nugent, R.A., III, Notter, D.R. \& Beal, W.E. (1988) Effects of ewe breed and ram exposure on estrous behavior in May and June. J. Anim. Sci. 66, 1363-1370.

Ortavant, R., Bocquier, F., Pelletier, J., Ravault, J.P., Thimonier, J. \& Volland-Nail, P. (1988) Seasonality of reproduction in sheep and its control by photoperiod. Aust. J. biol. Sci. 41, 69-85.

Ravault, J.P (1976) Prolactin in the ram: Seasonal variations in the concentration of blood plasma from birth until three years old. Acta endocr., Copenh. 83, $720-725$.

Ravault, J.P. \& Ortavant, R. (1977) Light control of prolactin secretion in sheep. Evidence for a photoinducible phase during a diurnal rhythm. Annls Biol. anim. Biochim. Biophys. 17, 459-473.

Robinson, J.E. \& Karsch, F.J. (1984) Refractoriness to inductive day lengths terminates the breeding season of the Suffolk ewe. Biol. Reprod. 31, 656663.

Robinson, J.E. \& Karsch, F.J. (1987) Photoperiodic history and a changing melatonin pattern can determine the neuroendocrine response of the ewe to daylength. J. Reprod. Fert. 80, 159-165.

Robinson, J.E., Radford, H.M. \& Karsch, F.J. (1985a) Seasonal changes in pulsatile luteinizing hormone (LH) secretion in the ewe: relationship of frequency of $\mathrm{LH}$ pulses to day length and response to estradiol negative feedback. Biol. Reprod. 33, 324-334.

Robinson, J.E., Wayne, N.L. \& Karsch, F.J. (1985b) Refractoriness to inhibitory day lengths initiates the breeding season of the Suffolk ewe. Biol. Reprod. 32, 1024-1030.

Skaggs, C.L., Able, B.V. \& Stevenson, J.S. (1986) Pulsatile or continuous infusion of luteinizing hormonereleasing hormone and hormonal concentrations in prepubertal beef heifers. J. Anim. Sci. 62, 1034-1048.

Thomas, G.B., Pearce, D.T., Oldham, C.M., Martin, G.B. \& Lindasy, D.R. (1988) Effects of breed, ovarian steroids and season on the pulsatile secretion of $\mathrm{LH}$ in ovariectomized ewes. J. Reprod. Fert. 84, 313-324. Downloaded from Bioscientifica.com at 04/26/2023 09:01:16AM 
Webster, G.M. \& Haresign, W. (1983) Seasonal changes in $\mathrm{LH}$ and prolactin concentrations in ewes of two breeds. J. Reprod. Fert. 67, 465-471.

Wiggins, E.L., Barker, H.B. \& Miller, W.W., III (1970) Estrual activity in open Rambouillet ewes. J. Anim. Sci. 30, 405-408.

Worthy, K. \& Haresign, W. (1983) Evidence that the onset of seasonal anoestrus in the ewe may be independent of increasing prolactin concentrations and daylength. J. Reprod. Fert. 69, 41-48.
Worthy, K., Haresign, W., Dodson, S., McLeod, B.J., Foxcroft, G.R. \& Haynes, N.B. (1985) Evidence that the onset of the breeding season of the ewe may be independent of decreasing plasma prolactin concentrations. J. Reprod. Fert. 75, 237-246.

Received 8 September 1989 